\title{
COMPARISON OF CLONIDINE AND DEXMEDETOMIDINE IN BLUNTING THE CARDIOVASCULAR RESPONSES TO LARYNGOSCOPY AND TRACHEAL INTUBATION- A RANDOMIZED CONTROL STUDY
}

\author{
Senthil Kumar Kaliannan', Khaja Mohideen Sherfudeen², Pavan Kumar Dammalapati ${ }^{3}$ \\ ${ }_{1}^{1}$ Consultant Anaesthesiologist, Department of Anaesthesiology, Kauvery Hospitals, Trichy, Tamilnadu, India. \\ ${ }^{2}$ Consultant Anaesthesiologist, Department of Anaesthesiology, Muthumeenakshi Hospitals, Pudukkottai, Tamilnadu, India. \\ ${ }^{3}$ Consultant Anaesthesiologist, Department of Anaesthesiology, Kauvery Hospitals, Trichy, Tamilnadu, India.
}

\begin{abstract}
BACKGROUND

Laryngoscopy and tracheal intubation activate the sympathetic system resulting in tachycardia and hypertension. Alpha- 2 agonists like clonidine and dexmedetomidine blunt the sympathoadrenal stimulation caused by tracheal intubation and surgery. This study aims to compare the effect of intravenous dexmedetomidine and clonidine on the stress response resulting from laryngoscopy and endotracheal intubation.
\end{abstract}

\section{METHODS}

This is a prospective randomized control study. Ninety adult patients of age between 18 and 55 years in American Society of Anesthesiologists physical status I and II were included in this study. Patients were randomly allocated into Group A (Placebo), Group C (Clonidine) and Group D (Dexmedetomidine) of 30 patients each. In the operation theatre, placebo $(0.9 \%$ normal saline, clonidine $(2 \mu \mathrm{g} / \mathrm{kg})$ or dexmedetomidine $(1 \mu \mathrm{g} / \mathrm{kg})$ or $)$ diluted in $20 \mathrm{ml} \mathrm{NaCl} 0.9 \%$ were infused over a period of $10 \mathrm{~min}$. Systolic blood pressure (SBP) and diastolic blood pressure (DBP), mean arterial pressure (MAP), and heart rate (HR) were recorded. Hypotension, bradycardia and sedation scores were also noted. Statistical analysis was done using Excel Data Plugin. Data is represented as mean \pm standard deviation. Chi-square and two-way analysis of variance were used $\mathrm{p}<0.05$ was considered significant.

\section{RESULTS}

HR, SBP, DBP and MAP were significantly lower in Group C and D compared to Group A at all times after intubation. Comparing Group C and D also, there was a significant difference in HR, MAP (till $6^{\text {th }}$ minute after intubation), SBP and DBP (till $4^{\text {th }}$ minute after intubation).

\section{CONCLUSIONS}

Dexmedetomidine $1 \mu \mathrm{g} / \mathrm{kg}$ and clonidine $2 \mu \mathrm{g} / \mathrm{kg}$ used in blunting the laryngoscopic response produces significant reduction in $\mathrm{HR}$ and BP compared to placebo. But dexmedetomidine produced better attenuation of intubation response compared to clonidine with no major side effects.

HOW TO CITE THIS ARTICLE: Kaliannan SK, Sherfudeen KM, Dammalapati PK. Comparison of clonidine and dexmedetomidine in blunting the cardiovascular responses to laryngoscopy and tracheal intubation- a randomized control study. J. Evolution Med. Dent. Sci. 2019;8(21):1730-1734, DOI: $10.14260 /$ jemds/2019/380

\section{BACKGROUND}

Laryngoscopy and endotracheal intubation are potent noxious stimuli which activate the sympathetic nervous system, inducing tachycardia and hypertension. These changes are maximum immediately after intubation and last for 5-10 minutes. ${ }^{[1]}$ These hemodynamic events are especially dangerous in patients with coronary artery disease, cardiac dysrhythmia, cardiomyopathy, congestive heart failure and hypertension.[2] Various treatment methods like topical or intravenous (IV) lidocaine, opioids, inhaled anaesthetics, vasodilators, calcium channel blockers or adrenergic blockers have been used successfully in blunting the laryngoscopic response.[3]

'Financial or Other Competing Interest': None.

Submission 09-04-2019, Peer Review 14-05-2019,

Acceptance 20-05-2019, Published 27-05-2019.

Corresponding Author:

Khaja Mohideen Sherfudeen,

Muthumeenakshi Hospitals,

South $4^{\text {th }}$ Street, Marthandapuram,

Pudukkottai-622001

Tamilnadu, India

E-mail: khaja.sherfudeen@gmail.com

DOI: $10.14260 /$ jemds $/ 2019 / 380$

\section{(c) (i) $(3)$}

Alpha-2 agonists like clonidine and dexmedetomidine is being used recently for controlling the sympathoadrenal stimulation caused by tracheal intubation and surgery. These drugs stimulate the alpha- 2 adrenergic inhibitory neurons in the medullary vasomotor centre and hence decreasing the sympathetic nervous system outflow from central nervous system. ${ }^{2]}$ Dexmedetomidine is a highly selective a 2adrenoreceptor agonist with short duration of action compared to clonidine.[4]

The purpose of this study was to compare the effect of clonidine and dexmedetomidine in blunting the hemodynamic response after laryngoscopy and intubation.

\section{METHODS}

This prospective, randomized, controlled study involving 90 adult patients was conducted after approval from institutional ethics committee and written informed consent from the patients. Sample size was calculated based on the assumption that there would be a $30 \%$ reduction in the mean HR following drug administration; this required 25 patients in each group for results to be significant (With $\alpha=0.05$ and power of $80 \%$ ). We enrolled 30 patients in each group considering possibility of some protocol violations. 


\section{RESULTS}

\begin{tabular}{|c|c|c|c|c|}
\hline Variable & Group A & Group C & Group D & p Value \\
\hline $\begin{array}{c}\text { Mean age } \pm \text { SD } \\
\text { (years) }\end{array}$ & $\begin{array}{c}35.22 \pm \\
8.44\end{array}$ & $\begin{array}{c}36.46 \pm \\
9.32\end{array}$ & $\begin{array}{c}36.12 \pm \\
1.44\end{array}$ & 0.379 \\
\hline $\begin{array}{c}\text { Mean weight } \pm \text { SD } \\
(\mathrm{kg})\end{array}$ & $\begin{array}{c}66.44 \pm \\
7.82\end{array}$ & $\begin{array}{c}68.28 \pm \\
9.32\end{array}$ & $\begin{array}{c}64.18 \pm \\
8.92\end{array}$ & 0.621 \\
\hline $\begin{array}{c}\text { Mean height } \pm \text { SD } \\
(\mathrm{cm})\end{array}$ & $\begin{array}{c}160.56 \pm \\
6.72\end{array}$ & $\begin{array}{c}159.68 \pm \\
8.55\end{array}$ & $\begin{array}{c}161.82 \pm \\
7.54\end{array}$ & 0.832 \\
\hline Male: Female & $19: 11$ & $20: 10$ & $18: 12$ & 0.828 \\
\hline ASA status(1/2) & $28 / 2$ & $26 / 4$ & $25 / 5$ & 0.732 \\
\hline \multicolumn{5}{|c|}{ Table 1. Demographic Characteristics of The Patients } \\
\hline
\end{tabular}

\begin{tabular}{|c|c|c|c|c|c|}
\hline Variable & $\begin{array}{c}\text { Group } \\
\text { A }\end{array}$ & $\begin{array}{c}\text { Group } \\
\text { C }\end{array}$ & $\begin{array}{c}\text { Group } \\
\text { D }\end{array}$ & \multicolumn{2}{|c|}{$\begin{array}{c}\text { Significance of } \\
\text { Difference } \\
\text { (ANOVA) FP }\end{array}$} \\
\hline Baseline & $\begin{array}{c}74.49 \pm \\
8.11\end{array}$ & $\begin{array}{c}77.26 \pm \\
8.76\end{array}$ & $\begin{array}{c}78.23 \pm \\
8.65\end{array}$ & 1.102 & 0.282 \\
\hline $\begin{array}{c}\text { After drug } \\
\text { infusion }\end{array}$ & $\begin{array}{c}75.02 \pm \\
10.66\end{array}$ & $\begin{array}{c}73.55 \pm \\
9.65\end{array}$ & $\begin{array}{c}77.69 \pm \\
9.98\end{array}$ & 3.025 & 0.122 \\
\hline $\begin{array}{c}\text { After } \\
\text { intubation (AI) }\end{array}$ & $\begin{array}{c}105.38 \pm \\
8.43\end{array}$ & $\begin{array}{c}97.67 \pm \\
9.54\end{array}$ & $\begin{array}{c}82.81 \pm \\
8.96\end{array}$ & 25.454 & $<0.001$ \\
\hline 2 mins (AI) & $\begin{array}{c}100.48 \pm \\
8.58\end{array}$ & $\begin{array}{c}90.71 \pm \\
8.98\end{array}$ & $\begin{array}{c}76.20 \pm \\
8.76\end{array}$ & 25.485 & $<0.001$ \\
\hline 4 mins (AI) & $\begin{array}{c}94.90 \pm \\
7.98\end{array}$ & $\begin{array}{c}83.82 \pm \\
8.43\end{array}$ & $\begin{array}{c}74.37 \pm \\
7.76\end{array}$ & 18.342 & $<0.001$ \\
\hline 6 mins (AI) & $\begin{array}{c}88.11 \pm \\
10.45\end{array}$ & $\begin{array}{c}77.80 \pm \\
10.54\end{array}$ & $\begin{array}{c}71.67 \pm \\
9.89\end{array}$ & 16.587 & $<0.001$ \\
\hline 8 mins (AI) & $\begin{array}{c}85.58 \pm \\
8.32\end{array}$ & $\begin{array}{c}72.04 . \pm \\
8.54\end{array}$ & $\begin{array}{c}69.43 \pm \\
8.54\end{array}$ & 11.432 & $<0.001$ \\
\hline 10 mins (AI) & $\begin{array}{c}82.46 \pm \\
9.34\end{array}$ & $\begin{array}{c}71.72 \pm \\
9.49\end{array}$ & $\begin{array}{c}68.61 \pm \\
9.76\end{array}$ & 10.345 & $<0.001$ \\
\hline
\end{tabular}

Table 2. Comparison of Heart Rates Between the Groups $A, C$ and $D$

\begin{tabular}{|c|c|c|c|c|c|}
\hline \multirow[t]{2}{*}{ Variable } & \multirow[t]{2}{*}{$\begin{array}{c}\text { Group } \\
\text { A }\end{array}$} & \multirow[t]{2}{*}{$\begin{array}{l}\text { Group } \\
\text { C }\end{array}$} & \multirow[t]{2}{*}{$\begin{array}{l}\text { Group } \\
\text { D }\end{array}$} & \multicolumn{2}{|c|}{$\begin{array}{l}\text { Significance of } \\
\text { Difference } \\
\text { (ANOVA) }\end{array}$} \\
\hline & & & & $\mathbf{F}$ & p \\
\hline Baseline & $\begin{array}{c}90.33 \pm \\
7.56\end{array}$ & $\begin{array}{c}92.37 \pm \\
7.66\end{array}$ & $\begin{array}{c}93.56 \pm \\
6.98\end{array}$ & 0.629 & 0.528 \\
\hline $\begin{array}{l}\text { After drug } \\
\text { infusion }\end{array}$ & $\begin{array}{c}90.61 \pm \\
8.62\end{array}$ & $\begin{array}{c}87.51 \pm \\
9.02\end{array}$ & $\begin{array}{c}82.35 \pm \\
8.94\end{array}$ & 14.402 & $<0.001$ \\
\hline $\begin{array}{c}\text { After } \\
\text { intubation } \\
\text { (AI) }\end{array}$ & $\begin{array}{c}114.69 \pm \\
5.77\end{array}$ & $\begin{array}{c}106.84 \pm \\
6.56\end{array}$ & $\begin{array}{c}96.71 \pm \\
7.45\end{array}$ & 35.561 & $<0.001$ \\
\hline 2 mins (AI) & $\begin{array}{c}112.58 \pm \\
6.87\end{array}$ & $\begin{array}{c}97.15 \pm \\
6.88\end{array}$ & $\begin{array}{c}89.54 \pm \\
6.87\end{array}$ & 38.430 & $<0.001$ \\
\hline 4 mins (AI) & $\begin{array}{c}107.81 \pm \\
8.76\end{array}$ & $\begin{array}{c}92.84 \pm \\
7.53\end{array}$ & $\begin{array}{c}82.69 \pm \\
7.64\end{array}$ & 36.492 & $<0.001$ \\
\hline 6 mins (AI) & $\begin{array}{c}103.37 \pm \\
7.44\end{array}$ & $\begin{array}{c}87.13 \pm \\
8.12\end{array}$ & $\begin{array}{c}82.41 \pm \\
5.56\end{array}$ & 31.827 & $<0.001$ \\
\hline 8 mins (AI) & $\begin{array}{c}101.59 \pm \\
7.65\end{array}$ & $\begin{array}{c}87.22 \pm \\
8.54\end{array}$ & $\begin{array}{c}83.38 \pm \\
6.64\end{array}$ & 28.381 & $<0$ \\
\hline 10 mins $(A I)$ & $\begin{array}{c}96.03 \pm \\
5.56 \\
\end{array}$ & $\begin{array}{c}86.73 \pm \\
6.51 \\
\end{array}$ & $\begin{array}{c}83.47 \pm \\
6.21 \\
\end{array}$ & 22.419 & $<0.001$ \\
\hline
\end{tabular}

Table 3. Comparison of Mean Arterial Pressure Between Groups A, C and D

\begin{tabular}{|c|c|c|c|}
\hline Sedation Score & Group A & Group C & Group D \\
\hline 1 & $3(10 \%)$ & $0(0 \%)$ & $0(0 \%)$ \\
\hline 2 & $24(80 \%)$ & $10(33.33 \%)$ & $2(6.67 \%)$ \\
\hline 3 & $3(10 \%)$ & $20(66.66 \%)$ & $22(73.33 \%)$ \\
\hline 4 & $0(0 \%)$ & $0(0 \%)$ & $6(20 \%)$ \\
\hline 5 & $0(0 \%)$ & $0(0 \%)$ & $0(\%)$ \\
\hline 6 & $0(0 \%)$ & $0(0 \%)$ & $0(\%)$ \\
\hline \multicolumn{4}{|c|}{ Table 4. Comparison of Sedation Score at 10 } \\
Extubation \\
\hline
\end{tabular}
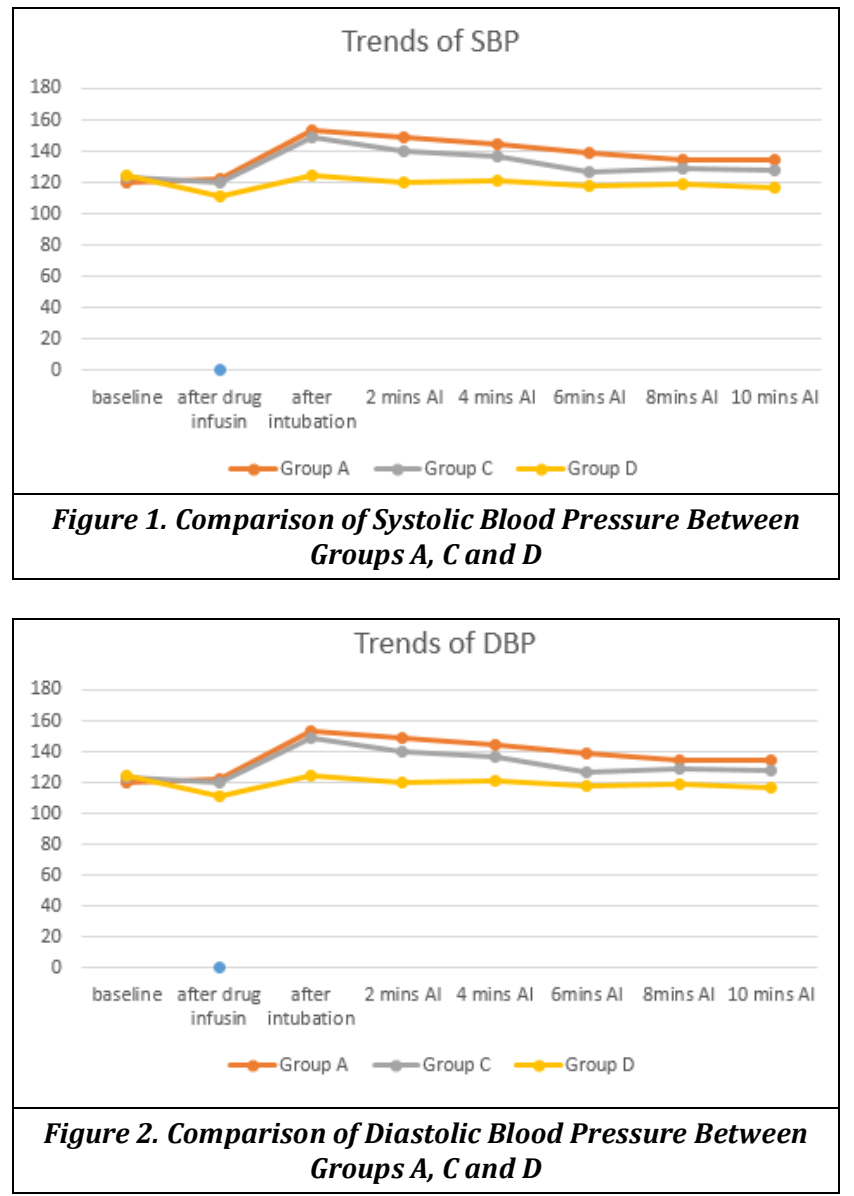

Patients aged between 18 and 55 years in American Society of Anaesthesiologists (ASA) physical status I and II undergoing elective surgeries under general anaesthesia were included in our study. Patients with predicted difficult airway, on preoperative $\beta$-blocker therapy, systemic illness such as hypertension, significant coronary artery disease, morbid obesity, moderate to severe anaemia, hepatic failure, and renal failure were excluded from the study.

The patients were randomly allocated to three groups (Group A, C, D) with the help of a computer-generated table of random numbers.

Group A/Placebo group (30 patients) - received $20 \mathrm{ml}$ $\mathrm{NaCl} 0.9 \%$ over $10 \mathrm{~min}$.

Group C/Clonidine group (30 patients) - received clonidine $(2 \mu \mathrm{g} / \mathrm{kg}$ ) diluted in $20 \mathrm{ml} \mathrm{NaCl} 0.9 \%$ over $10 \mathrm{~min}$.

Group D/Dexmedetomidine group (30 patients) received dexmedetomidine $(1 \mu \mathrm{g} / \mathrm{kg})$ diluted in $20 \mathrm{ml} \mathrm{NaCl}$ $0.9 \%$ over $10 \mathrm{~min}$.

All patients were premedicated with oral lorazepam $2 \mathrm{mg}$ and ranitidine $150 \mathrm{mg}$ night before and $2 \mathrm{hrs}$ prior to surgery. Inside the OT after giving the study drug, glycopyrrolate 0.2 mg was given intravenously. Patient was induced with fentanyl $2 \mu \mathrm{g} / \mathrm{kg}$, propofol $2 \mathrm{mg} / \mathrm{kg}$ and intubated after paralysing with vecuronium $0.1 \mathrm{mg} / \mathrm{kg}$. Intraoperatively maintenance of anaesthesia done with sevoflurane, Oxygen: nitrous oxide 50:50, vecuronium and fentanyl. End of surgery patient was reversed with neostigmine $0.05 \mathrm{mg} / \mathrm{kg}$ and glycopyrrolate $0.01 \mathrm{mg} / \mathrm{kg}$ and extubated. Patient was then kept in recovery room for 2 hours and then shifted to ward.

Heart rate (HR), systolic blood pressure (SBP), diastolic blood pressure (DBP), and mean arterial pressure (MAP) were recorded baseline, after study drug administration, after 
induction and 1, 2, 3, 5, and 10 min after intubation. Sedation level was assessed using Ramsay sedation score 10 minutes post extubation.

Hypotension (reduction in arterial blood pressure of $20 \%$ or more from baseline) was treated by fluid bolus and followed $6 \mathrm{mg}$ of ephedrine. Bradycardia (HR $<45$ beats/minute or $20 \%$ decrease from baseline) was treated with $0.6 \mathrm{mg}$ bolus of atropine.

Statistical analysis was done using Excel Data Plugin. Data is represented as mean \pm standard deviation. Chi-square test (for sex and ASA status) and two-way analysis of variance test were used. $p<0.05$ was considered significant.

Comparison of the three study groups for age, weight, height, gender ratio and ASA status revealed no statistically significant intergroup difference ( $p>0.05$ ) [Table 1].

There was no difference in baseline HR among the groups ( $p>0.05)$. After administration of the drug, changes in HR occurred in group C and D compared to group A, but it was not statistically significant. But after intubation to till 10 minutes after intubation, the HR in group $C$ and $D$ were lower compared to group A. Also, when comparing group C and group $D$ the fall in heart rate was statistically significant after intubation to till 6 mins after intubation $(p<0.05)$. At $8^{\text {th }}$ and $10^{\text {th }}$ minute the fall in HR in group D was not statistically significant. [Table 2]

Baseline MAP among the groups were similar ( $p>0.05)$. After drug infusion and intubation, the changes in MAP in group $C$ was not statistically significant $(p>0.05)$ compared to group $\mathrm{A}$, but the changes in MAP in group D compared to group A was significant. Thereafter there was significant difference in MAP in group C and D compared to group A. Between group $C$ and $D$, the difference in MAP was significant $(\mathrm{p}<0.05)$ in group $\mathrm{D}$ compared to group $\mathrm{C}$ after drug infusion to till 6 th minute after intubation. Thereafter the fall in group D was not statistically significant compared to group C. [Table 3]

Baseline SBP among the groups were identical ( $p>0.05)$. After drug infusion and intubation, the difference in SBP in group $C$ was not statistically significant $(p>0.05)$ compared to group A, but the changes in SBP in group D compared to group A was significant $(p<0.001)$. Thereafter there was significant difference in SBP in group $C$ and D compared to group $A(p<0.001)$. Between group $C$ and $D$, the changes in SBP was significant $(\mathrm{p}<0.05)$ in group $D$ compared to group $C$ after drug infusion to till 4 th min after intubation. Thereafter the changes in group D was not statistically significant compared to group C. [Figure 1]

There was no difference in baseline DBP among the groups ( $p>0.05$ ). After drug infusion the fall in DBP in group $C$ was not statistically significant $(p>0.05)$ compared to group $\mathrm{A}$, but the fall in DBP in group D compared to group A was significant $(\mathrm{p}<0.05 \backslash 01)$. Thereafter there was significant difference in DBP in group C and D compared to group A $(p<0.001)$. Between group $C$ and $D$, the changes in DBP was significant $(\mathrm{p}<0.05)$ in group $\mathrm{D}$ compared to group $\mathrm{C}$ after drug infusion to till 4 th minute after intubation. [Figure 2]

None of the patient in group $A$ and group $C$ had a sedation score of more than 3 . In group D six patients $(20 \%)$ had sedation score of 4 and none of the patients had score of more than 4. Sedation scores of group C and D were statistically significant compared to group A $(p<0.001)$. Also, between group $C$ and $D$ higher sedation score was found in group D compared to group C. $(\mathrm{p}<0.001)$. [Table 4]

\section{DISCUSSION}

Laryngoscopy and intubation activate the sympathoadrenal system resulting in hypertension, tachycardia, cardiac arrhythmia and increased myocardial oxygen consumption. Also, there is an acute increase in plasma concentration of epinephrine and norepinephrine.[5]

Various factors like age, used medications, duration of intubation, depth of anaesthesia affect the cardiovascular responses during endotracheal intubation and laryngoscopy. of these the duration of laryngoscopy and depth of anaesthesia are the most important factors. ${ }^{[6]}$ In our study the duration of laryngoscopy was kept less than 15 seconds. And patients with anticipated difficult airway were excluded from the study. Neuromuscular monitoring and depth of anaesthesia monitors were not used in our study. Laryngoscopy was done after 3 minutes of giving $0.1 \mathrm{mg} / \mathrm{kg}$ of vecuronium.

Centrally acting alpha 2 agonists like clonidine and dexmedetomidine offer a unique pharmacological profile with sedation, sympatholysis, analgesia, cardiovascular stability and with a great advantage of minimal respiratory depression. It maintains the hemodynamic stability by blunting the stress induced sympathoadrenal responses to intubation during surgery and during emergence from anaesthesia.[7] Number of studies has been done using clonidine and dexmedetomidine in varying doses for blunting the intubation response. Zalunardo et al., [8] Altan et al., ${ }^{[9]}$ and Ray et al.[10] have successfully used $2 \mu \mathrm{g} / \mathrm{kg}$ of clonidine for attenuating hemodynamic response to tracheal intubation. Arora et al., in his study comparing two doses of clonidine (1 $\mu \mathrm{g} / \mathrm{kg}$ and $2 \mu \mathrm{g} / \mathrm{kg}$ ) for obtunding the laryngoscopic response has found that both the doses are helpful in blunting the laryngoscopic response but patients receiving clonidine 2 $\mu \mathrm{g} / \mathrm{kg}$ were more sedated. Hence, he concluded that minimal dose of IV clonidine $1 \mu \mathrm{g} / \mathrm{kg}$ cause maximum attenuation of pressor response with minimal side effects like hypotension and sedation. ${ }^{[2]}$

Menda et al., [11] Keniya et al., [12] and Bajwa et al.[13] in their studies have used dexmedetomidine $1 \mu \mathrm{g} / \mathrm{kg}$ IV and found it to be effective in attenuating the pressor response during laryngoscopy. Studies comparing different doses of dexmedetomidine has produced varying results. Smitha et al. compared the effect of 0.5 and $1 \mu \mathrm{g} / \mathrm{kg}$ of dexmedetomidine with normal saline in attenuating stress response and found out that dexmedetomidine $1 \mu \mathrm{g} / \mathrm{kg}$ was more effective than dexmedetomidine $0.5 \mu \mathrm{g} / \mathrm{kg}$ in controlling haemodynamic responses to tracheal intubation.[14] But Jarineshin et al., has found no significant difference between $0.5-1 \mu \mathrm{g} / \mathrm{kg}$ of dexmedetomidine in reducing $\mathrm{HR}$ and MAP during intubation.[15] Sebastian, et al studied 0.5 and $0.75 \mu \mathrm{g} / \mathrm{kg}$ of dexmedetomidine and said dexmedetomidine 0.75 $\mu \mathrm{g} / \mathrm{kg}$ attenuated the haemodynamic stress response to laryngoscopy and endotracheal intubation completely compared to $0.5 \mu \mathrm{g} / \mathrm{kg}$.[16]

Most studies comparing the effect of clonidine and dexmedetomidine in different doses e.g. clonidine $2 \mu \mathrm{g} / \mathrm{kg}$ and dexmedetomidine $1 \mu \mathrm{g} / \mathrm{kg},[1]$ clonidine $3 \mu \mathrm{g} / \mathrm{kg}$ and dexmedetomidine $0.5 \mu \mathrm{g} / \mathrm{kg},[17]$ clonidine $1 \mu \mathrm{g} / \mathrm{kg}$ and dexmedetomidine $1 \mu \mathrm{g} / \mathrm{kg},{ }^{[18]}$ clonidine $1 \mu \mathrm{g} / \mathrm{kg}$ and 
dexmedetomidine $0.5 \mu \mathrm{g} / \mathrm{kg}$ and $1 \mu \mathrm{g} / \mathrm{kg}^{[19]}$ showed varying results. Based on these studies we decided to compare the effect of clonidine $2 \mu \mathrm{g} / \mathrm{kg}$ and dexmedetomidine $1 \mu \mathrm{g} / \mathrm{kg}$ in blunting the laryngoscopic response.

The baseline parameters for demography and hemodynamic variables were matched in the three groups.

In our study we found the mean SBP, DBP and MAP in the dexmedetomidine group remained close to the baseline throughout the study period showing a statistically significant difference from both the placebo and clonidine groups. In the clonidine group, the mean SBP, DBP and MAP were significantly lower compared to placebo group at all-time intervals, but the extent of the difference between placebo and dexmedetomidine group was higher as compared to that of the clonidine group. Similar trends were obtained for HR too.

In the placebo group, maximum mean SBP was observed to be $153.59 \pm 8.73 \mathrm{~mm}$ of $\mathrm{Hg}$ after intubation which was significantly higher compared to both clonidine (148.44. \pm $8.54 \mathrm{~mm}$ of $\mathrm{Hg}$ ) as well as dexmedetomidine (124.51 \pm 8.1 $\mathrm{mm}$ of $\mathrm{Hg}$ ) group at the corresponding time interval. In the placebo group and dexmedetomidine group, the minimum mean SBP at any post intubation interval was $134.32 \pm 5.77$ $\mathrm{mm}$ of $\mathrm{Hg}$ and $116.61 \pm 6.99 \mathrm{~mm}$ of $\mathrm{Hg}$ at 10 min whereas in clonidine group the minimum value was at $6^{\text {th }}$ minute (126.56 $\pm 7.21 \mathrm{~mm}$ of $\mathrm{Hg}$ ).

As regards the hike in mean SBP between induction to intubation intervals, the change was distinctly sharp in the placebo group (from $122.54 \pm 7.66$ to $153.59 \pm 8.73 \mathrm{~mm}$ of $\mathrm{Hg}$ ) as compared to clonidine group (119.82 \pm 8.46 to $148.44 \pm$ $8.54 \mathrm{~mm}$ of $\mathrm{Hg}$ ) and dexmedetomidine group (110.83 \pm 7.7 to $124.51 \pm 8.1 \mathrm{~mm}$ of $\mathrm{Hg}$ ). The minimum to a maximum range of SBP was between $120.53 \pm 6.71$ and $153.59 \pm 8.73 \mathrm{~mm}$ of $\mathrm{Hg}$ in the placebo group, from $119.82 \pm 8.46$ to $148.44 \pm 8.54 \mathrm{~mm}$ $\mathrm{Hg}$ in clonidine group and from $110.96 \pm 7.7$ to $124.51 \pm 8.1$ $\mathrm{mm}$ of $\mathrm{Hg}$ in the dexmedetomidine group.

Similar pattern of hemodynamic changes was observed in studies comparing clonidine and dexmedetomidine. But the doses they used was different comparing to our studies. Hussain et al also compared clonidine $2 \mu \mathrm{g} / \mathrm{kg}$ and dexmedetomidine $1 \mu \mathrm{g} / \mathrm{kg}$ and found the results same as our study.[1] Sarkar et al used a higher dose of clonidine in their study and compared clonidine $3 \mu \mathrm{g} / \mathrm{kg}$ and dexmedetomidine $0.5 \mu \mathrm{g} / \mathrm{kg}$ and found results similar to our study.[17]

In placebo and clonidine group, none of the patient developed hypotension or bradycardia. One patient in group D had developed hypotension after drug infusion which was managed by infusing intravenous fluid without inotropes.

Sedation levels in group D and C were significantly higher compared to group A. But both in group C and D none of the patients required supplemental oxygen. Arora et al in his study comparing clonidine 1 $\mu \mathrm{g} / \mathrm{kg}$ and $2 \mu \mathrm{g} / \mathrm{kg}$ found that $2 \mu \mathrm{g} / \mathrm{kg}$ to cause more hypotension and sedation. ${ }^{[2]}$ But in our study we found that clonidine did not cause any hypotension. But clonidine group were more sedated compared to saline group. But there was no desaturation or requirement of supplemental oxygen.

Our study results are in contradiction to study by Kakkar $\mathrm{A}$ et al., who compared clonidine $1 \mu \mathrm{g} / \mathrm{kg}$ and dexmedetomidine $0.5 \mu \mathrm{g} / \mathrm{kg}$ and $1 \mu \mathrm{g} / \mathrm{kg}$ and concluded that all three groups were good in attenuating the laryngoscopic response, but clonidine was associated with less side effects.[19]

Our study had few limitations like invasive blood pressure was not monitored, plasma catecholamines level were not quantified, anaesthesia depth was not monitored, intraoperative usage of fentanyl and inhalational agents were not compared.

\section{CONCLUSIONS}

Dexmedetomidine $1 \mu \mathrm{g} / \mathrm{kg}$ and clonidine $2 \mu \mathrm{g} / \mathrm{kg}$ used in blunting the laryngoscopic response produces significant reduction in $\mathrm{HR}$ and $\mathrm{BP}$ compared to placebo. But dexmedetomidine produced better attenuation of intubation response compared to clonidine with no major side effects.

\section{REFERENCES}

[1] Hussain SY, Karmarkar A, Jain D. Evaluation and comparison of clonidine and dexmedetomidine for attenuation of hemodynamic response to laryngoscopy and intubation: a randomized controlled study. Anesth Essays Res 2018;12(4):792-6.

[2] Arora S, Kulkarni A, Bhargava AK. Attenuation of hemodynamic response to laryngoscopy and orotracheal intubation using intravenous clonidine. J Anaesthesiol Clin Pharmacol 2015;31(1):110-4.

[3] Srivastava VK, Agrawal S, Gautam SK, et al. Comparative evaluation of esmolol and dexmedetomidine for attenuation of sympathomimetic response to laryngoscopy and intubation in neurosurgical patients. J Anaesthesiol Clin Pharmacol 2015;31(2):186-90.

[4] Coursin DB, Coursin DB, Maccioli GA. Dexmedetomidine. Curr Opin Crit Care 2001;7(4):2216.

[5] Hassan HG, el-Sharkawy TY, Renck H, et al. Hemodynamic and catecholamine response to laryngoscopy with vs. without endotracheal intubation. Acta Anaesthesiol Scand 1991;35(5):442-7.

[6] Bucx M, van Geel R, Scheck P, et al. Cardiovascular effects of forces applied during laryngoscopy. The importance of tracheal intubation. Anaesthesia 1992;47(12):1029-33.

[7] Scheinin B, Lindgren L, Randell $\mathrm{T}$, et al. Dexmedetomidine attenuates sympathoadrenal responses to tracheal intubation and reduces the need for thiopentone and preoperative fentanyl. $\mathrm{Br} \mathrm{J}$ Anaesth 1992;68(2):126-31.

[8] Zalunardo MP, Zollinger A, Spahn DR, et al. Preoperative clonidine attenuates stress response during emergence from anesthesia. J Clin Anesth 2000;12(5):343-9.

[9] Altan A, Turgut N, Yildiz F, et al. Effects of magnesium sulphate and clonidine on propofol consumption, haemodynamics and postoperative recovery. $\mathrm{Br} \mathrm{J}$ Anaesth 2005;94(4):438-41.

[10] Ray M, Bhattacharjee DP, Hajra B, et al. Effect of clonidine and magnesium sulphate on anaesthetic consumption, haemodynamics and postoperative recovery: a comparative study. Indian J Anaesth 2010;54(2):137-41. 
[11] Menda F, Köner O, Sayin M, et al. Dexmedetomidine as an adjunct to anesthetic induction to attenuate hemodynamic response to endotracheal intubation in patients undergoing fast-track CABG. Ann Card Anaesth 2010;13(1):16-21.

[12] Keniya VM, Ladi S, Naphade R. Dexmedetomidine attenuates sympathoadrenal response to tracheal intubation and reduces perioperative anaesthetic requirement. Indian J Anaesth 2011;55(4):352-7.

[13] Bajwa SJ, Kaur J, Singh A, et al. Attenuation of pressor response and dose sparing of opioids and anaesthetics with pre-operative dexmedetomidine. Indian J Anaesth 2012;56(2):123-8.

[14] Smitha KS, Shukla D, Sathesha M, et al. Comparison of two different doses of dexmedetomidine in attenuating hemodynamic changes during laryngoscopy. J Evol Med Dent Sci 2014;3(61):135018.

[15] Jarineshin H, Abdolahzade Baghaei A, Fekrat F, et al. Comparison of two different doses of dexmedetomidine in attenuating cardiovascular responses during laryngoscopy and endotracheal intubation: a double blind, randomized, clinical trial study. J Med Life 2015;8(4):45-51.
[16] Sebastian B, Talikoti AT, Krishnamurthy D. Attenuation of haemodynamic responses to laryngoscopy and endotracheal intubation with intravenous dexmedetomidine: a comparison between two doses. Indian J Anaesth 2017;61(1):48-54.

[17] Sarkar A, Tripathi RK, Choubey S, et al. Comparison of effects of intravenous clonidine and dexmedetomidine for blunting pressor response during laryngoscopy and tracheal intubation: a randomized control study. Anesth Essays Res 2014;8(3):361-6.

[18] Ganesh N, Madhukrishna N. A comparative study between clonidine and dexmedetomidine in attenuation of pressor response during endotracheal intubation. Indian Journal of Clinical Anaesthesia 2018;5(2):244-8.

[19] Kakkar A, Tyagi A, Nabi N, et al. Comparision of clonidine and dexmedetomidine for attenuation of laryngoscopy and intubation response - a randomized controlled trial. J Clin Anesth 2016;33:283-8. 